\title{
A BEHAVIORAL ANALYSIS OF DIRECTORS' LIABILITY FOR NEGLIGENCE
}

\author{
Alfred F. Conard*
}

\section{The Rules of Liability}

Directors of large corporations are sometimes compared, with considerable justice, to the supreme party council in a one-party state. Potentates of countries commonly regarded as dictatorial might look with envy on American corporate directors not only for the funds of money of which they dispose, but also for the security of their tenure. ${ }^{1}$ But there are many ways in which directors are unlike a dictatorial presidium. One of the distinctions, and perhaps the most important, is directors' liability to pay damages when they make mistakes. ${ }^{2}$ Professor Joseph W. Bishop, Jr., writing of the "failure of dircctors to dircct," has declared that "the only legal deterrent to such conduct, and perhaps the only deterrent of any sort, is the fear of civil liability."3

The civil liability of directors may be usefully divided for analysis into two parts. The first part is liability for self-serving conduct-for example, by paying themselves excessive compensation, or by making contracts favorable to their own interests. The second part is liability for negligence-for example, by making an unwise investment based upon an incorrect financial statement. It is the latter type of liability that this article will discuss.

Negligence liability may, in turn, be divided into two parts. One of these is directors' liability to the corporation for any failure to

* Professor of Law, University of Michigan. A.B. 1932, Grinnell College; LL.B., 1936, University of Pennsylvania; LL.M., 1939, J.S.D., 1942, Columbia University.

1. For a classic analysis of directors' absolutism, see A. BerLe, POWER Without Property (1959). See also J. Livingston, The American Stockholder 15 (1958).

THE FOLLOWING HEREINAFTER CITATIONS ARE USED IN THIS ARTICLE:

all-ABa Course of Study on Insuring Corporate Personnel and Professional ADVISERS UNDER EXPANDing ConCEPTS of ResponsibiLITY (1970) [hereinafter cited as ALIABA STUDY].

A. Conard, J. Morgan, R. Pratt, C. Voltz \& R. Bombaugh, Automobile Accident Costs and Payments (1964) [hereinafter cited as Conard, et al.].

2. See generally W. KNepper, Liability of Corporate Officers and DiRectors (1969). For a discussion of current applications of liability, see Hershman, Officers' and Directors' Responsibilities and Liabilities, Opening Remarks, 27 Bus. Law. 1 (Special Issue, Feb. 1972).

3. Bishop, Sitting Ducks and Decoy Ducks: New Trends in the Indemnification of Corporate Directors and Officers, 77 YALE L.J. 1078, 1093 (1968). 
manage its affairs with normal skill and diligence. ${ }^{4}$ The other is directors' liability to securities buyers and to creditors for any failure to state with reasonable accuracy the state of affairs of the company; the most prominent example of this type of liability is that imposed by section 11 of the federal Securities Act of 1933.8 There are various other types of negligence liability-such as liability to creditors for incurring debts beyond the corporation's probable ability to pay, and for deceiving creditors by issuing misleading financial statements ${ }^{7}$ - which are omitted from the present discussion in the belief that the questions which they present are fundamentally similar to those presented by liability under the Securities Act.

What this article will examine is not the excellence of the principles of conduct which these rules express, but the human behavior

4. A few classic cases involving liability to the corporation, the facts of which will be referrcd to in the ensuing discussion, include:

Bates v. Dresser, 251 U.S. 524 (1920). Even though dwindling assets and remarks by informants might have prompted an earlier investigation, the cashier of a small bank embezzled funds over a period of years. The president was held liable, and the other directors were vindicated.

Barnes v. Andrews, 298 F. 614 (S.D.N.Y. 1924). A corporation had failed because it had continued to pay salaries to executives and other employees who were accomplishing nothing. An outside director was not held liable, although he admittedly had devoted inadequate attention to the company's affairs, because it was not demonstrated that more attention would have reduced the corporation's losses.

Litwin v. Allen, 25 N.Y.S.2d 667 (Sup. Ct. 1940). Directors of a bank voted to buy Missouri Pacific bonds under an agreement to resell them upon demand; the effect of the decision was to insure a loss if the bonds decreased in value, but to deny any chance of gain if their value increased and the previous owner tendered a demand for the bonds. The directors were held liable for the loss sustained on the bonds during the period of the repurchase option.

Selheimer v. Manganese Corp. of America, 423 Pa. 563, 224 A.2d 634 (1966). A corporation failed because of the continuation of an inefficient operation at an old plant in Paterson, N.J., instead of shifting to a more suitable facility at Colwyn, $\mathrm{Pa}$., although a prospeclus had promised such a shift in operations. A finding of liability was affirmed, but the damage assessment was remanded to determine the extent of the corporation's losses which were duc to the directors' error in delaying transfer of operations, as distinguished from other causes.

For a more extended discussion of these and other cases, see Cary \& Harris, Standards of Conduct Under Common Law, Present Day Statutes and the Model Act, 27 Bus, LAw, 61 (Special Issue, Feb. 1972).

5. The outstanding example of this type of directors' liability, imposed by section 11 of the Securities Act of 1933, 15 U.S.C. $\$ 77 \mathrm{k}$ (1970), is Escott v. BarChris Constr. Corp., 283 F. Supp. 643 (S.D.N.Y. 1968). See generally Applebaum \& McDowell, Indentnification Against Securities Acts Liabilities, 27 Bus. Law. 131 (Special Issue, Feb. 1972); Latty, Prospectus Liability-The BarChris Case, 1970 J. Bus. LAw 65; Ruder, Wheat \& Loss, Standards of Conduct Under the Federal Securities Acts, 27 Bus. Law. 75 (Special Issue, Feb. 1972).

6. 15 U.S.C. $\$ 77 k$ (1970).

7. See Bystrom v. Villard, 175 App. Div. 433, 162 N.Y.S. 100 (Sup. Ct. 1916) (president and director held liable to stock purchaser who relied upon false statements in prospectus which defendants failed to verify). See also H. HenN, Law of CoRPORations $\$ 234$ (2d ed. 1970). 
which is likely to result from the rules' existence. Since the totality of behavior responsive to the rules of liability has not been observed, the subject will be examined by means of conjectural "models" of behavior. One of them is a "model" in the older sense of that concatenation of consequences which would most perfectly justify the law as it stands. The other is a "model" in the contemporary sense of a set of hypotheses which seem likely to exist in fact.

\section{The Models of Behavior}

\section{An Idealistic Model of Behavior}

Ideally, directors might be expected to respond to the rule of liability in the following ways:

Compliance (paying the corporation's or investors' losses). Whenever directors' errors which result in losses to the corporation are detected, the directors would draw on their bank accounts and other resources, and repay the corporation for the losses suffered ${ }^{8}$ or, in the case of false statements in registration procedures, directors would reimburse the investment losses of securities buyers. ${ }^{9}$ Either type of payment would be beneficial to investors because it would relieve them of losses occasioned by directors' errors. Consequently, investment would be safer than otherwise, capital would become available at lower rates of return, and production costs would be lowered, with the ultimate benefit of lower prices or higher profits, or both. Admittedly, a certain amount of director impoverishment would result from this type of transfer of funds. Although this is not in itself a virtue, director improverishment may have valuable secondary consequences, which will be noted next.

$A$ voidance by circumspection. In their eagerness to avoid impoverishment through compliance with the rules of liability, directors would exercise enhanced skill and diligence in the discharge of their duties. Consequently, corporations would become more efficient, and, in turn, consumers and investors would receive further benefits.

Avoidance by retreat. While some directors would continue to exercise their duties with intensified care, others would perceive their own unwillingness or ineptitude to reach the standards required and, therefore, decide not to be directors. This consequence would grad-

\footnotetext{
8. This alternative was followed in Litwin v. Allen, 25 N.Y.S.2d 667 (Sup. Ct. 1940), and in Selheimer v. Manganese Corp. of America, 423 Pa. 563, 224 A.2d 634 (1966). See note 4 supra.
} 
ually eliminate unsuitable persons from boards of directors, so that the efforts of those who would continue to serve would be even more effective.

If the foregoing model accurately describes prevailing director behavior, the existing rules of liability are working splendidly, and there is no need to pursue the subject further. If the model appears to be far removcd from reality, however, one may usefully attempt to hypothesize a more probable model of directors' behavior.

\section{A Realistic Model of Directors' Behavior}

Avoidance of application of the rule. One of the outstanding characteristics of the human animal is his disposition to avoid punishment and obtain satisfaction by circuitous means other than those contemplated by rulemakers. Circuity is indeed one of the basic arts of business management-most conspicuous in planning transactions to minimize tax incidence, to maximize financial resources without encountering securities regulations, and to entice customers without violating fair trade rules. These talents, which have long been devoted to avoiding other risks, are equally available to cope with the menace of directors' liability.

The intensity of the impulse to avoid can only be appreciated when the magnitude of the possible liabilities is contemplated. In a famous case involving the maneuvers of Guaranty Trust Company to save Alleghany Corporation, plausible claims were made for liabilities of over ten million dollars, though the court actually imposed liability to the extent of about half a million dollars. ${ }^{10}$ In Selheimer v. Manganese Corp. of America, "involving a small corporation with a capital of about half a million dollars, the lower court charged the directors with liability for losses of 383 thousand dollars, though on appeal the case was remanded to reduce this amount. With a normally vivid imagination, a director might then visualize losses reaching astronomic levels - for example, the mistake of the Ford directors in manufacturing the Edsel has been estimated to have cost 350 million dollars, ${ }^{12}$ and the mistake of duPont directors in Corfam to have cost the company 100 million dollars. ${ }^{13}$ Under section 11 of the

9. See Escott v. BarChris Constr. Corp., 283 F. Supp. 643 (S.D.N.Y. 1968),

10. See Litwin v. Allen, 25 N.Y.S.2d 667 (Sup. Ct. 1940).

11. 423 Pa. 563, 224 A.2d 634 (1966).

12. J. Brooks, The Fate of The Edsel and Other Business Adventures 67 (1963).

13. Cooney, A Giant Stirs: DuPont Co. Planners Stake Future Growth on Current Changes, Wall St. J., Jan. 20, 1972, at 1, col. 6. 
Securities Act of 1933, a director could become liable for the entire amount of the registered share issue, which could easily run into tens of millions. ${ }^{14}$

Who would undertake a directorship with even a moderate probability of being liable for any of these amounts in return for directors' fees of a few thousand dollars? ${ }^{15}$ Perhaps it would not scare off Ralph Nader, who reportedly has no wealth to lose, ${ }^{16}$ but, by the same token, the possibility of huge losses would not deter him from negligence. Perhaps Henry Ford would not be scared off, since his concern with preserving his billion-dollar stake in the company justifies the risk of 500 million dollars; but if he could work as well through a dummy director, that course of action would seem to be the most sensible approach. For a moderately successful engineer, lawyer, banker or executive, however, it would be simple improvidence to risk losing his fortune of a few hundred thousand or a few million dollars, when the only gain would be a few thousands in fees. If he wants to serve his fellow men, he can acquire as much virtue with less risk on boards of churches and Audubon societies. For the middle class representative of blacks, women or the environmentwith a fortune consisting of an equity in a six room house and a few thousand dollars in life insurance and children's education endowments-assuming directorial risks would be profligate. So it would not be surprising if directors demanded an effective plan of liabilityavoidance, and gave a fair amount of thought to keeping it operative.

1. Indemnification. Directors are likely to share the propensity of other human beings to regard their mistakes as the products of the unforeseeability of human events, rather than as failures to exercise the skill and care of normally prudent managers. Consequently, directors are likely to regard it as only fair that their corporations reimburse them for the expenses they incur in defending against claims of negligence and for any amounts for which they may be required to reimburse the corporation. Corporation laws have been

14. See Escott v. BarChris Constr. Corp., 283 F. Supp. 643 (S.D.N.Y. 1968). In 1970, 1,850 corporate issues vere registered with the SEC, aggregating 25 billion dollars, indicating a mean offering amount of over 10 million dollars. 1970 SEC ANN. REP. 216.

15. See Cary \& Harris, supra note 4; Garrett, Duties and Liabilities of Corporate Directors, Introduction-General Survey, 22 Bus. LAw. 29, 33 (1966); Hershman, supra note 2; Garrct, Marsh, McDowell, Bishop, Delancey, Meara \& Sebring, Symposium: Duties and Liabilities of Corporate Directors, 22 Bus. LAw. 29, 124 (1966). See also Farrell \& Murphy, Comments on the Theme: Why Should Anyone Want to be a Director?, 27 Bus. LAw. 7 (Special Issue, Feb. 1972).

16. Meet Ralph Nader, Newsweek, Jan. 22, 1968, at 65-67. 
generously amended to permit such indemnification, ${ }^{17}$ and directors can reasonably be expected to make the fullest permissible use of them. ${ }^{18}$

There are, however, some obstacles to the indemnification procedure. First, the directors who are to be reimbursed cannot vote on their own claims; nevertheless, if there are disinterested directors, they may be expected to hold a favorable view of their fellowdirectors, since otherwise they would not be serving on the same board. The sympathetic attitude of disinterested directors will naturally be reinforced by the fact that they owe their positions to the votes of the proxy committee, which usually includes the principal executives who must have concurred in whatever decisions the board has made. If the matter requires shareholder approval, the stockholders may be expected to vote as recommended by the directors since, if the shareholders did not have confidence in the management, most would have sold their shares and invested in another company. ${ }^{10}$

The second obstacle to the indemnification procedure will be the terms of the indemnification statutes which preclude indemnification when directors have been found to be at fault. ${ }^{20}$ However, no such finding can be made if the case is settled before judgment. Relevant data suggest that more than 90 percent of such cases will be termi-

17. Influential patterns of directors' indemnification laws are provided in ABA MoDEL Bus. Corp. Act ANn. \$ 5 (2d ed. I971); Del. Code ANn. tit. 8, § I45 (Supp. 1968); N.Y. Bus. Corp. Law $\$ 721-27$ (McKinney 1963), as amended, (McKinney Supp. 1970). Their origins date from 1950 (Model), 1967 (Delaware), and 194I (New York), but each statute hus been frequently revised. For analyses of these and similar laws and their effects, sce ABA MOdel Bus. CORP. ACT ANN. $\$ 5$, Comment (2d ed. 1971) (containing an exhaustive bibliography and statutory citations); ALI-ABA STUDY I 18-37; W. KNEPPER, stupra note 2, at 157. 7I; G. WASHINGton \& J. Bishop, IndemNifying the Corporate Executive 112-68 (1963); Applebaum \& McDowell, supra note 5; Bishop, New Cure for an Old Ailment: Insurance Against Directors' and Officers' Liability, 22 Bus. LAw. 92, 97-102 (1966); Cheek, Control of Corporate Indemnification: A Proposed Statute, 22 VAND. L. REV. 255 (1969); Klink, Chalif, Bishop \& Arsht, Liabilities Which Can Be Covered Under State Statutes and Corporate Bylaws, 27 Bus. LAw. I09 (Special Issue, Feb. 1972); Note, Indentmification of the Corporate Insider: Directors' and Officers' Liability Insurance, 54 MiNN. L. REv. 667 (1970).

18. For comments on the practice of indemnification, see Garrett, Marsh, McDowell, Bishop, DeLancey, Meara \& Sebring, supra note I5, at 123-28.

19. This point of view is commonly asserted with regard to the attitudes of small shareholders. See, e.g., J. Livingston, supra note I, at 22-26, 33-38 (1958); Manning, Book Revicw, 67 YALE L.J. I477, I483 (1958).

20. See ABA Model Bus. Corp. Act ANn. $\$ 5(b)$ (2d ed. 1971); Del. Code ANN. tit. 8. $\$ 145$ (b) (Supp. 1968) (precluding indemnification in a derivative suit if the director has been "adjudged to be liable for negligence or misconduct"). The New York statute precludes indem. nifying any part of the settlement in a derivative action but allows reimbursement of defense expenses. N.Y. Bus. CoRP. LAW $\S 722$ (b) (McKinney 1963). 
nated prior to judgment. A survey in the 1930's and early 1940's showed that 95 percent of shareholders' derivative suits were terminated otherwise than by a judgment for the plaintiff..$^{21}$ Most of these suits were probably against directors, although the report on the survey does not so specify. More recent data on automobile injury litigation show that over 85 percent of the cases terminated otherwise than by a judgment for the claimant. ${ }^{22}$ Thus, indemnification is likely to be permissible in 90 percent or more of the suits against directors. Consequently, it may be hypothesized that directors will escape payment from their own pockets in a very high percentage of the cases where claims are made and prosecuted.

2. Liability insurance. To the extent that risks of directors' negligence liability persist in spite of indemnification practice, liability risks may be further reduced by officers' and directors' liability insurance. ${ }^{23}$ Before the 1960's, this form of insurance seems to have been used infrequently, ${ }^{24}$ probably because the threat of liability was not credible to most directors. Among the developments which stimulated the great leap forward of liability insurance, the most dramatic was the decision of Escott v. BarChris Construction Corp. ${ }^{25}$ which

21. See F. Wood, Survey and Report Regarding Derivative Suits 32 (1944). Wood's figures have been re-analyzed to eliminate the bias in his presentation. Combining the closelyheld and publicly-held corporations and eliminating the cases as to which final disposition was unknown, 931 cases are within the category of final dispositions. Of this number, $45(5 \%)$ were "recoveries"; 287 (31\%) were settled; 337 (36\%) dismissed; and $262(28 \%)$ discontinued. There have been extcnsive changes, of course, in the law since this report, but there does not appear to be any reason to expect a radical change in the settlement rate.

22. See ConARD, et al. 241 , showing that 15 percent of filed automobile personal injury cases reached trial, and 2 percent reached appeal. The more recent and comprehensive Department of Transportation (DOT) study does not present aggregate quantities from which a percentage could be calculated, but presents a graphic figure which appears consistent with the Conard report. The DOT study also presents a graphic figure dividing the cases reaching tria! between those settled before verdict and those terminated by judgment; a visual inspection indicates that about as many were settled before verdict as afterward. DOT, AUTOMOBILE InSURANCE ANd Compensation Study, Automobile ACCident Litigation 29-30 (1970).

23. See generally ALI-ABA STUDY; W. KNEPPER, supra note 2, at 173-93; Applebaum \& McDowell, supra note 5, at 137-38; Bishop, supra note 17; Bishop, supra note 3; Hinsey \& DeLancey, Directors' and Officers' Liability Insurance: An Approach to Its Evaluation and a Checklist, 23 Bus. Law. 869 (1968); Hinsey, DeLancey, Stahl \& Kramer, What Existing D \& O Policies Cover, 27 Bus. Law. 147 (Special Issue, Feb. 1972); Mace, Directors' and Officers' Liability Insurance, 85 Banking L.J. 39 (1968); Scott, Fears and Phobias in Thrift Institutions, 88 Banking L.J. 124 (1970); Note, Public Policy and Directors' Liability Insurance, 67 Colum. L. Rev. 716 (1967); Note, Liability Insurance for Corporate Executives, 80 HARv. L. Rev. 648 (1967); Wall St. J., June 29, 1966, at 1, col. 6.

24. See ALI-ABA Study 5-8; Bishop, supra note 17, at 103.

25. 283 F. Supp. 643 (S.D.N.Y. 1968). See note 5 supra and accompanying text. 
demonstrated how ordinary businessmen could become personally liable for the aggregate amount of a stock or bond flotation.

No data seem to be available on the number of corporations carrying this type of insurance, but casual conversations with corporation counsel indicate that such insurance is nearly universal among publicly-held companies. ${ }^{26} \mathrm{~A}$ typical answer to an inquiry is "of course we take officers' and directors' liability insurance. Anybody would be crazy to be a director for a company that does not." Although Professor Bishop has attacked this attitude as unsound, his observations serve to confirm that this point of view is prevalent. ${ }^{27}$

Liability insurance protects directors and officers in two ways. Policies are normally written both to insure the corporation against expenses of indemnification and to insure the officers and directors against payments on accounts of liability, including attorneys' fees and other costs of defense..$^{28}$ One effect of the insurance is therefore to facilitate a company's indemnification of its directors, since, with the exception of premium costs, the company no longer bears the expense of indemnification. The other effect is to reduce the amount which the directors might otherwise have to pay in those cases where the corporation is unwilling to indemnify.

However, the use of insurance implies that directors will have to pay something, because the standard form of policy provides for a deductible amount to be borne entirely by the insureds and for apportionment of the risk above this amount in a ratio of 95 percent for the insurer and 5 percent for the insured. The insured, of course, bears the entire loss beyond the policy limits, and policy clauses generally forbid the corporation to indemnify the directors for the uncovered liabilities. ${ }^{29}$

It is unclear to what extent corporations will choose to indemnify their directors without utilizing insurance, thus relieving directors of 100 percent of their costs, and to what extent they will call on insurance, with the consequence of relieving the directors of only 95 per-

26. See Bishop, supra note 3, at 1079 n.4. See note 27 infra.

27. Vincent Stahl, speaking in March, 1969, stated that he was surprised to find that 50 percent of a sample of large corporations were carrying such insurance. ALI-ABA STUDY 8. In December, 1970, it was reported that 93 of 144 respondent manufacturing companies were insured. Fisher \& Brown, Some Consequences of Directors' Liability, CONFERENCE BOARD ReCORD, Dec., 1970, at 30.

28. For an analysis of policy terms, see ALI-ABA STUDY 70-99. See also the sample clauses set forth in the appendix of that study.

29. See Hinsey, DeLancey, Stahl \& Kramer, supra note 23, at 148-49, 157-58. Sample clauses are set forth in ALI-ABA StuDY A-3, A-14, A-21. 
cent of their liability. It is probable that both methods will be used, so that, in the end, directors will be relieved of between 95 and 100 percent of the losses for which they are liable.

3. Refusal to serve. If the available indemnification procedures and insurance coverage do not provide a sense of security, people may refuse to serve as directors. ${ }^{30} \mathrm{~A}$ frequent observation of corporate counsel is that respected directors are harder to obtain these days. In practice, this seems to mean that many directorial candidates initially decline to serve and can be persuaded to do so only by assurances that the company carries liability insurance to protect them and by the existence of a substantial level of directors' fees. When these considerations fail to persuade a potential director, the explanations for the failure are often that insurance does not cover all risks, it never pays for the time lost if a liability suit is brought, and it is inherently incapable of neutralizing the injury to prestige and peace of mind occasioned by a liability suit.

Ironically, indemnification and insurance may even aggravate the danger of lost time, reputation, and composure caused by liability suits. As juries and judges become aware that the amounts which they assess against directors are not taken from the defendants' personal wealth, there is a likelihood that larger sums will be awarded, further stimulating the litigiousness of plaintiffs' attorneys.

Unfortunately, it is not certain that the nominees who refuse to serve are the least competent ones, as hypothesized in the "idealistic model" presented above. ${ }^{31}$ The greater the wealth and reputation of a candidate, the less willing he may be to assume a position of risk. The quality of "prudence," so valued in a money manager, is highly incompatible with incurring risks of million-dollar liabilities. An enterprise with stains on its corporate history and badly in need of better advisers may thus be peculiarly handicapped in procuring competent directors.

Some critics of directors' liability insurance seem to assume that the right kind of director would be one who would have no fear of liability, because he would plan to exercise due care. By similar reasoning, the right kind of automobile driver would be one who fails to carry automobile liability insurance, because he intends to have no accidents.

4. Building paper shelters. Another probable avoidance response

30. See Cary \& Harris, supra note 4; Farrell \& Murphy, supra note 15.

31. See pages 897-98 supra. 
to the threat of liability claims is to expend great effort on establishing a record of diligence. Directors may refuse to make decisions unless they are supplied with opinions of accountants certifying the accuracy of financial statements, appraisers' estimates of the value of properties, forecasts by management consultants of profit prospects, engineers' analyses of production costs, and lawyers' opinions about the legality of a course of conduct. Directors may insist, as a condition of affirmative action, that the documents take strong positive views of a proposed course, so as to prove on any later audit that the directors used "due diligence." ${ }^{32}$ Such an attitude would force managers to find and use consultants who tend more toward optimism than toward candor and illumination. In this way, the fear of liability may tend to degrade, rather than to elevate, the decisional processes of directors.

5. Intensification of diligence. Finally, the menace of liability may increase diligence, of which there are many types. Diligence in a motorist may take the form of watching more alertly to avoid impacts with other vehicles, or watching more alertly to avoid violating traffic rules such as stop signals, speed limits and median lines, or watching more alertly for police who might detect violations of traffic rules. In somewhat parallel fashion, one might compare diligence in maximizing profits, diligence in avoiding losses, diligence in avoiding participation in crucial decisions, diligence in creating an appearance of diligence in whatever decisions are made, and diligence in establishing programs of indemnification and insurance which will avoid liability when mistakes occur.

It seems quite likely that the directors in the leading cases of liability ${ }^{33}$ would think that their errors had resulted from their zeal in trying to keep the company afloat in difficult times, rather than from any laxity. Consequently, these directors would be less likely to try to improve the quality of their decisions than to shelter themselves by procedural precautions, indemnification and insurance. A director found liable is somewhat in the position of a basketball player who is booed by the crowd. He may become more tense, but he knows no better how to get the ball into the basket than he did before the hooting began.

The principal occasion for improved diligence as a consequence

32. See Applebaum \& McDowell, supra note 5, at 134-36.

33. See Litwin v. Allen, 25 N.Y.S.2d 667 (Sup. Ct. 1940); Selheimer v. Manganese Corp. of America, 423 Pa. 563, 224 A.2d 634 (1966). 
of liability arises when a failure has disclosed a particular procedure which should have been employed to reduce risk. For example, In re McKesson \& Robbins, Inc. ${ }^{34}$ taught accountants to make field checks of inventory, and taught directors to require that accountants certify to having made those field checks. This procedure is helpful if embezzlers obligingly persist in the same routines of deception, but it does not cope effectively with the inventiveness of embezzlers who manage to falsify the gauges of salad oil tanks. ${ }^{35}$

A current opportunity to evaluate the diligence stimulated by liability is presented by the "due diligence" procedures developed in response to the BarChris disaster. To a large extent these procedures consist of procuring written statements from lawyers, accountants and others for the sole purpose of showing "due diligence." ${ }^{36}$

The extent of net gain resulting from an increased perception of the liability threat is enigmatic. Certainly, directors are trying harder to be diligent. Some directors certainly deliberate more carefully and reach sounder conclusions than they would if not threatened with liability; others certainly give increased attention to routines of verification which divert their attention from solving the company's problems toward a ritual of regularity. This writer would guess that liability enhances the latter tendency more than the former, but each reader should make his own conjecture.

\section{Stalling the Liability Machine}

Aside from the ingenuity of mankind in avoiding the application of any penalty, there are usually a number of obstacles in the processes through which the penalty is applied which prevent it from working, even when no active avoidance devices are employed. Legal principles are like home-made bombs, which often fail to ignite even if they are not intercepted by the police. Discussed below are some of the reasons why the rule of directors' liability frequently remains inactivated even without active obstruction.

1. Nobody knows. There is nothing to make it immediately evident when a directorial error has caused a corporate loss, or when a registration statement has been materially false. Where suits against directors have been brought, they have often followed an exposure by

34. SEC Accounting Series Release No. 19 (Dec. 5, 1940), reprinted in 4 CCH FED. SEC.

L. REP. ๆๆ 72020-37 (1964).

35. Ameco Salad Oil Swindle, Forbes, Dec. 1, 1965, at 20.

36. See Applebaum \& McDowell, supra note 5, at 131-38. 
a congressional committee or an investigation report of a governmental commission. ${ }^{37}$

2. Corporations don't cry. When corporate directors learn that some of them have made a mistake, it usually means that all of them are responsible for the mistake since directors act collectively. Directors probably share the general human disinclination to recognize one's own mistakes, the stronger disinclination to regard the mistakes as negligent, and the still stronger tendency to doubt that losses which have occurred resulted from the mistakes they made. Even when directors clearly perceive that they have negligently caused a loss, it may appear to them that to enforce the corporation's right against themselves would occasion the even greater cost of dissuading themselves, or equally gifted substitutes, from consenting to serve.

This obstacle may, of course, be avoided in various circumstances. If the corporation has become insolvent, the decision to sue may be made by a trustee in bankruptcy, who is subject to quite different tensions. ${ }^{38}$ If the guilty managers have sold out their interest, ${ }^{39}$ the new management will feel no inhibitions about suing the old. However, merely to mention these cases suggests their exceptional nature.

The obstacle of the corporation's disinclination to sue directors is only partially circumvented by the right of a shareholder to bring a derivative suit. The exercise of this right is impeded in the same way as that of a securities buyer to sue for a false registration statement-that is, by the improbability that an outside shareholder will discover the key error.

3. Expense of investigation, preparation and suit. Very few share-

37. The suit in Litwin v. Allen, 25 N.Y.S.2d 667 (Sup. Ct. 1940), for example, was closely related to facts regarding J.P. Morgan's financial operations exposed by official investigations. Recent suits against investment company advisors for excessive fees also seem to be related to SEC studies of mutual funds.

38. A receiver brought the action in Barnes v. Andrews, 298 F. 614 (S.D.N.Y. 1924). Cf. Selheimer v. Manganese Corp. of America, 423 Pa. 563, 224 A.2d 634 (1966), where a receiver intervened in an action brought by a stockholders' committee which was formed by a director. An instance of current interest is related in N.Y. Times, Feb. 11, 1972, at 47, col. 6.

39. An example of this phenomenon is evident in the "looting" cases. See Insuranshares Corp. v. Northern Fiscal Corp., 35 F. Supp. 22 (E.D. Pa. 1940), where tbe corporation, under new management, sued the former prineipal shareholders as well as one of the directors. Insuranshares indicates the possibility of the corporation's suing for negligence, although the suit in that case was actually for restitution of an illicit profit on sale of control. It is rarc, of course, that the corporation survives the looting. Accordingly, other looting suits have been brought by bankruptcy trustees or liquidators. See, e.g., Superintendent of Ins. v. Bankers Life and Cas. Co., 404 U.S. 6 (1971); Gerdes v. Reynolds, 28 N.Y.S.2d 622 (Sup. Ct. 1941). 
holders, even if rich and powerful, would invest money in the hazard of a suit against directors. The preparation of such a suit always involves expensive investigation and hundreds of hours of legal study. Thus, such suits are brought chiefly when lawyers are willing to invest, at their own risk, the necessary hours of investigation and preparation. In several important states, preparation involves organizing a mass of shareholders whose aggregate holdings are worth at least 50 thousand dollars. ${ }^{40}$

Although some lawyers are willing to make the investment for such suits, they are likely to do so only when the probable rewards of success are rather high and can be perceived to be high even before the investigation is begun. This factor serves to diminish the proportion of detected malfeasances which are likely to be prosecuted by complainants.

\section{Transaction Costs}

Coercive measures generally involve high transaction costs ${ }^{41}$ since people do not willingly give up their money or their freedom. Directors' liability cases are no exception. Some data on the amounts of attorneys' fees in this area are available because the fees of successful plaintiffs' attorneys are usually assessed against the corporation by court order. Professor Hornstein determined from a survey of court records that the average allowance for all expenses was about 20 percent of the benefit conferred on the corporation. The percentage allowed was lower for the larger recoveries and higher for the smaller ones. ${ }^{42}$ Some very large awards have been made, such as the $\$ 1,876,000$ recovery in Zenn $v$. Anzalone, ${ }^{43}$ a case which involved Alleghany Corporation's control of Investors' Diversified Services, Inc. The percentage in these cases is calculated not simply on money paid over, but on prospective future gains as well. In Zenn, most of

40. See N.Y. Bus. Corp. Law $\S 627$ (McKinney 1963), as amended, (McKinney Supp. 1970). For a survey and analysis of other statutes, see 2 G. HORNSTEIN, Corporation Law AND Practice $\$ 722$ (1959).

41. For earlier comments on transaction costs in relation to tort claims, see CoNARD, et al. 102-04; T. Ison, THE Forensic LOTTERy 28 (1967); Calabresi, The Fault System and Accident Costs, 33 Law \& Contemp. Prob. 429, 437-39 (1968); Vickery, Automobile Accidents, Tort Law, Externalities and Insurance, 33 LAw \& Contemp. Prob. 464, $482-83$ (1968).

42. See 2 G. HoRnStein, supra note 40 , at 253. Data are also available in F. Wood, supra note 21 , at $79-81$. Since these figures relate to settlements made prior to the development of the rule requiring court approval of counsel fees, they cannot be presumed to indicate current practice.

43. 259 N.Y.S.2d 747 (Sup. Ct. 1965). 
the predicted benefit consisted of the value of giving the benefited corporation control of another by changing its shares from nonvoting to voting shares. ${ }^{44}$

In addition to plaintiffs' collection costs, corresponding expenses are incurred by the defense, whether borne by the individual defendants, by the corporations of which they are directors, or by liability insurers. Data on these costs are not a matter of record, and can only be estimated. They include the costs of defense not only in the cases where plaintiffs prevail but also in the numerous cases where the plaintiffs fail and their lawyers obtain nothing. ${ }^{45}$ In the aggregate, defense expenses seem likely to be as great as claimants' expenses, although to be on the safe side one might estimate them to be 10 percent of the benefits conferred by payments and settlements. Defensive and offensive expenses combined must, therefore, be equal to at least 30 percent of the benefits received by corporations and investors on account of directors' negligence liability.

When directors' liability is covered by insurance, the transactional costs increase by the costs of insurance acquisition and administration. These costs vary with different kinds of insurance and are conveniently viewed as the "retained premium"-that is, the fraction of the premium which the company does not pay out in benefits or settlements. In automobile liability insurance, the retained fraction is approximately 40 percent. $^{46}$ In fidelity insurance, which resembles directors' liability insurance in that it is concerned with employees' misfeasance, the retention rises to approximately 50 percent. ${ }^{47}$ In suretyship, it reaches approximately 65 percent. $^{48}$

44. The benefit attributed to the control value of exchanging non-voting for voting shares was variously estimated at eleven to nineteen, eight, five and one-half, or over five million dollars. Id. at 748-49.

45. The report in F. WOOD, supra note 21 , indicates that 36 percent of the derivative suits reported on were dismissed, and 28 percent were discontinued. The latter figure presumably means "discontinued without settlement," since there were other classifications for "scttled" cases. Thus, 64 percent of the terminated cases appear to have been wholly unsuccessful. These percentages have been calculated from the raw numbers, however, and thus differ from those offered by the report itself.

46. The premium retention is most conveniently obtained by finding the loss ratio and determining its complement. The aggregate loss ratio of automobile bodily injury liability insurance underwritten by major stock companies in 1968 was 61.9 percent of premiums written. Best's Aggregates \& Averages: Property-Liability 131 (1968). Howcver, tolal expenses and losses were 103 percent of premiums. Since premiums over an extended period must cover expenses, it is appropriate to read the retention as the remainder of 103, rather than of 100 . Thus, we find a retention rate of $(103-61.9)$ divided by 103 , which equals 40 percent.

47. Id. at 137.

48. Id. at 138 . 
No published figures are available on loss ratios in officers' and directors' liability insurance. Even if available, such figures would not be decisive because experience with this line of underwriting is limited. One can assume, however, that the premium retention will be high because this form of liability insurance coverage is quite uncompetitive. Very few companies are offering directors' liability insurance, and so there is very little competitive pressure on premiums. ${ }^{49}$

Under present circumstances, it seems likely that the retention rate will be at least 50 percent; of the remaining 50 percent paid out in settlements, claimants' lawyers will probably retain one fifth, ${ }^{50}$ so that the net benefits may be approximately 40 percent of the premium costs.

The premiums are usually paid in the ratio of 90 percent from the corporation and 10 percent from the directors. ${ }^{51}$ However, the necessity of paying premiums necessarily increases the costs of being a director, and it seems likely that directors' fees are increased, even if not explicitly, to the extent necessary to pay the premiums. Consequently, all the premiums are paid at the ultimate expense of the persons interested in the corporation. In a healthy corporation, this means principally at the expense of the shareholders; to the extent that the executives share profits, such payment would also be at their expense. In corporations which are experiencing financial difficulties, the expense may be ultimately borne by creditors, suppliers and employees, all of whom suffer in various ways from the ill fortunes of the enterprise.

\section{The Redistribution of Losses}

One of the principal benefits which is claimed for other types of liability systems is that losses are redistributed from an injury victim to others..$^{52}$ This function has been most extensively studied in connection with automobile injuries. ${ }^{53}$ In the absence of insurance, the

49. See Hinsey, DeLancey, Stahl \& Kramer, supra note 23, at 155-56.

50. See 2 G. HoRNSTEIN, supra note 40, at 253.

51. See Bishop, supra note 3, at 1090.

52. 2 F. Harper \& F. James, The Law of Torts $\$ 13.1-.7$ (1956). The theory, which is generally traced to Smith, Frolic and Detour, 23 CoLum. L. Rev. 444 (1923), was subjected to a particularly insightful critique in Calabresi, Some Thoughts on Risk Distribution and the Law of Torts, 70 YALE L.J. 499 (1961). See also CONARD, et al. 75-107.

53. See, e.g., W. Blum \& H. Kalven, Public Law Perspectives on a Private law Problem (1965); Calabresi, The Decision for Accidents: An Approach to Nonfault Allocation of Costs, 78 HaRv. L. Rev. 713 (1965); Conard, The Economic Treatment of Automobile Injuries, 63 MiCH. L. Rev. 279 (1964). 
payment of damages purports to shift loss from an injured person to someone else. But since average citizens are virtually judgment-proof, the shift takes place only when the "someone else" has more than average resources; the result is generally a shifting of resources from the richer to the poorer. This consequence is particularly attractive when the claimant is disabled and destitute, as in severe injury cases.

The greatest benefits of redistribution are seen, however, in the presence of liability insurance. In these cases, the losses will be borne eventually by the large community of premium payers, so that they will bear more lightly on each insured than on the particular injury victim. ${ }^{54}$ Redistribution of personal injury losses is a "humanitarian" gain because the premium expenses of all drivers are less painful than the sudden destitution of a disabled worker or orphaned family. Since premium payments are associated with automobile ownership, the visible costs of automobile ownership are increased, thus leading to a more accurate social cost accounting, which in turn leads to a more beneficial allocation of resources. . $^{55}$

The remainder of this section will consider how this type of analysis applies to directors' liability when coupled with indemnification procedures or with liability insurance.

1. Redistribution without indemnity or insurance. If directors' liability is enforced without indemnification or insurance, loss is shifted from the corporation or its investors to the directors. The payment to compensate for the loss is likely to be rather small in proportion to the loss for either of two reasons. Directors' resources are usually small in comparison with the losses which their mistakes can cause; furthermore, liability claims are likely to be compromised at a fraction of the losses sustained because of the legal uncertainties of enforcement..$^{56}$

At the same time, corporations or investors who enforce the claim are likely to incur considerable legal expense; their net benefit will not be over four-fifths of the disappointing sums collected. ${ }^{57}$ In a

\footnotetext{
54. See Conard, et al. 97-99.

55. This aspect is emphasized by Calabresi, supra note 52. See also CoNARD, et al. 92-97.

56. No reliable data have been discovered with respect to the ratio of repayments to claimcd or estimated losses in cases of directors' liability. In automobile negligence, it has been repeatedly demonstrated that when losses are substantial, payments are usually a small fraction thereof. One survey, for example, showed an average payment of 30 percent of losses over $\$ 25,000$. J. Volpe, Motor Vehicle Crash Losses and Their Compensation in the United States 36 (1971). Another study showed that the median victim of over $\$ 25,000$ in losses collected less than 25 percent of the total loss. Conard, et al. 179.

57. See note $\mathbf{4 2}$ supra and accompanying text.
} 
more remote way, the corporations and investors who are benefited by the recovery may suffer increased costs in inducing directors to serve in the future because the corporation may have to increase directors' fees or buy insurance coverage. In the end, the loss shift from the corporation and its investors as a class will be minimal. Even the situation of particular investors who collect proceeds from a suit against directors will probably not be noticeably improved.

2. Redistribution when liability is indemnified. The shifting of loss incidence is further diminished if directors' liabilities are indemnified. In the case of a director's liability to the corporation itself, the circularity is complete-that is, the corporation pays back whatever it collects, plus a substantial legal expense. In the case of liability under the securities laws to a purchaser of stock, the ultimate burden of the loss is borne by the whole body of shareholders in the corporation-of which the plaintiff is probably a part.

3. Redistribution when liability is insured. When the losses of the corporation or of its investors are covered by insurance, there is a preliminary shift of loss from the corporation or the securities buyers to the insurers along with an augmentation of loss through litigation and insurance expenses. However, since the insurers are compensated by the premiums of all the corporations who buy insurance, the loss is redistributed ultimately from one corporation or group of investors to a wider group of corporations and investors. The ultimate burden consists not only of the loss itself but of the added litigation and insurance costs.

4. Social advantages of redistribution. Social advantages of loss redistribution are harder to discern in relation to corporations and investors than in relation to personal injury victims. If the losses of Guaranty Trust Company's shareholders ${ }^{58}$ had been shifted to other trust companies by means of insurance, it is not evident that the shareholders of the other companies would have been better able to bear the losses than were Guaranty's own shareholders. By diminishing proportionately the profits of all insurance-buying trust companies, the attractiveness of trust company stocks would have decreased, although not by any perceptible amount. Prospective buyers of such stocks might have learned the same lesson simply by contemplating the lowered earnings of Guaranty Trust.

Greater advantages of loss redistribution may be found in 
Selheimer v. Manganese Corp. of America. ${ }^{59}$ In that case, the corporation failed because of the directors' failure to shift the plant to a more suitable facility, despite the fact that a prospectus had promised such a relocation. If the directors' liability had been fully insured, the bankrupt estate would have been significantly augmented to the benefit of creditors. At the same time, shareholders in other companies would have lost profits to the extent of the insurance premiums which their respective companies had paid. If the creditors of Manganese were unpaid laborers, there might have been a humanitarian gain. If the creditors were principally bondholders or mining companies, the humanitarian gain would have been negligible.

Gains in the accuracy of social cost accounting as a result of loss distribution are even more elusive. By virtue of the loss shift, and the resulting increased costs of doing business, shares of all insurancebuying companies would become somewhat less attractive, and the shares in Manganese, or any such corporation, would become slightly more attractive. Thus, it appears that social cost accounting is impaired more than it is improved.

Perhaps the most favorable example of loss redistribution by insurance would be found in a case similar to BarChris. ${ }^{60}$ The initial loss in that case fell on the buyers of the misdescribed debentures. If the liability had been insured, the loss would have been redistributed among the shareholders of other corporations which bought similar insurance. To the extent of the shift, the perils of buying debentures would be diminished, and the rewards of owning stock in insurancebuying companies would be reduced. If the debenture-buyers were widows and orphans, a humanitarian gain would result. If the buyers were pension funds, which is more likely, the loss shift from one group of investors to another would seem to have negligible social advantages. Considering the fact that the costs are doubled or tripled in the process of redistributing them, the social gain may even be negative.

\section{An Alternative Structure of Directors' Liability}

Although directors' liability seems to operate in a clumsy and expensive way, it does not necessarily deserve to be abolished. Even a very small percentage of improvement in the wisdom of directors'

59. 423 Pa. 563, 224 A.2d 634 (1966).

60. Escott v. BarChris Constr. Corp., 283 F. Supp. 643 (S.D.N.Y. 1968). 
decisions would be well worth buying. Indeed, in a trillion-dollar corporate-oriented economy, it is clear that even a minimal improvement in the wisdom of directorial decision making would be well worth achieving.

However, the low net output of the system suggests that it may be desirable to devise a more efficient mechanism for achieving the same goals. There is an immense waste in litigating over milliondollar liabilities, with lawyers' fees in proportion, when only a tiny fraction of the redistribution operates to punish directors or to benefit injured investors.

To eliminate the waste, and vitalize the deterrent, it would be sufficient to abolish indemnification and insurance. However, this approach would deter responsible persons from serving as directors. The objective, therefore, must be to find a means of dispensing with indemnification and insurance, while simultaneously restraining the destructive effects of the deterrent.

An imaginable solution would be a return to the legal principles of a less complicated era, when Judges Holmes and Hand applied the "business judgment rule." wiser than analyses which attempt to assess the entire corporate loss against each single director, their results will not provide satisfaction today. Few modern judges share the faith of Holmes and Hand that businessmen will do well enough if left to themselves; the Selheimer ${ }^{62}$ case illustrates a more contemporary judicial approach, and the Securities $\mathrm{Act}^{63}$ a more contemporary legislative view. If these developments have not annihilated the "business judgment rule," this legal doctrine received its coup de grace in the recent decision granting plaintiffs in derivative cases a right to jury trial. ${ }^{64}$

The solution, if there is one, must be to reduce the extent of director liability to the amount which a prudent man is willing to risk. ${ }^{65}$ The difficulty arises from the fact that courts have mechanically applied to directors' liability the classic measure of damages evolved in tort law-that is, the full measure of loss resulting from the tortfeasor's wrongful conduct. ${ }^{66}$

\footnotetext{
61. Bates v. Dresser, 251 U.S. 524 (1920); Barnes v. Andrews, 298 F. 614 (S.D.N.Y. 1924).

62. Selheimer v. Manganese Corp. of America, 423 Pa. 563, 224 A.2d 634 (1966).

63. Securities Act of 1933, 15 U.S.C. $\$ 77$ a et seq. (1970); Securities Exchange Act of 1934, 15 U.S.C. \$ 78 a et seq. (1970).

64. Ross v. Bernhard, 396 U.S. 531 (1970).

65. Cf. Ruder, Wheat \& Loss, supra note 5 , at 89.

66. This is the principle of the landmark case, In re Polemis, [1921] 3 K.B. 560, whereby
} 
The necessity of reducing the extent of director liability is evidenced by the current form of liability insurance, with its upper and lower limits and coinsurance in the middle. ${ }^{67}$ Professor Loss also acknowledges the necessity of setting a limit on individual liability- $\$ 25,000$-in the current revision of the federal securities acts. ${ }^{08}$ Whether the liability limit (and the insurance deductible) is set at $\$ 5,000$ or at $\$ 25,000$, the limit will be derisively small in some cases, and draconically large in others. In order to be effective but not catastrophic, the measure of liability must stand in a proper relation to what a director gains from his position. If his annual fees of $\$ 10,000$ drop to $\$ 5,000$ after taxes, his maximum liability could be limited to this amount. Perhaps it should be twice this amount, or perhaps one-half, but it should vary depending upon the director's compensation. For the director who is motivated by financial considerations, this limit should be sufficient; for others, it is irrelevant.

The risk of losing one's annual compensation would also bear very differently on outside than on inside directors. Since outside directors are presumed to have some other primary source of income, the loss of their directors' fees would mean only that such directors had rendered a gratuitous service. For inside directors, who are not presumed to have substantial outside income, the loss would be much more serious; but since insiders are directly dependent upon the wellbeing of the corporation, they also have much greater incentives to bear the risk.

To carry out this plan, Congress could pass a law limiting the negligence liability of a director in a registered corporation ${ }^{69}$ to his net after-tax income from the corporation for the year in which one or more violations of duty occurred. This might result in a liability of $\$ 5,000$ for an outside director and $\$ 100,000$ for an officer-director. At the same time, the statute would forbid indemnification of such liabilities, as well as prohibit insurance coverage against them. The law should cover not only the federal securities laws but also state

the careless stevedore who struck a spark was liable for blowing up a ship.

67. See notes 23-29 supra and accompanying text. For a discussion of policy terms, sce ALI-ABA STUDY.

68. See Ruder, Wheat \& Loss, supra note 5, at 89.

69. "Registcred" companies should include all those registered under section $12(\mathrm{~g})$ of the Securities Exchange Act of 1934, 15 U.S.C. $\$ 78 /$ (1970), by reason of assets excecding $\$ 1,000,000$ and shareholders exceeding 500 , companies whose sccuritics are registered on a stock exchange under section 12(b) of the same statute, and investment companies registered under the Investment Company Act of 1940, 15 U.S.C. $\$ 80 \mathrm{a}-1$ (1970). 
securities laws and common-law principles of negligence and fiduciary duty. This coverage is appropriate because interstate corporations need to be liberated from the dual entanglements of catastrophic directors' liabilities and the expensive but useless encumbrances of indemnification and insurance. Like other federal liabilities, this form of directors' liability should be assertable by a shareholder without the impediment of state law requirements of contemporaneous shareholding and security for expenses. Payment of indemnification and insurance premiums would stop, but this would have no noticeable effect on corporate profits.

The effect of such a law would be to reduce immensely the amount of litigation over negligence. Since prospects of million-dollar verdicts would no longer exist, there would be no point in either side's incurring a quarter of a million dollars in legal expenses. As a result, questions of director negligence would be settled much more expeditiously and cheaply.

The total effect of the change on liability suits cannot be estimated without considering at the same time what would be done with regard to directors' liability for illicit profits obtained through selfdealing, short term trading, or trading on inside information. This engaging study would require another article as long as the present one. Consequently, the complete design of a legislative reform and a model of its aftermath must be left for another occasion.

\section{An Alternative Insurance Structure: No Fault?}

Since directors' liability insurance tends to spread the costs of directors' mistakes throughout the community of corporate investors, one is tempted to consider a system of "no-fault" insurance whereby corporations would simply insure themselves and their investors against loss. ${ }^{70}$ However, "loss" is too undefineable to lend itself to insurance coverage. To give the coverage any effective definition, it would have to be restricted to losses caused by blamable mistakes, which takes us right back to directors' liability insurance.

Perhaps a no-fault coverage could be designed for securities flotations which are accompanied by material misrepresentations, as in

70. For a vigorous advocacy of the no-fault insurance idea in automobile accidents, see $J$. O'Connell, The INJury INDUStry and the Remedy of No-Fault INSURANCe 94-105 (1971). See also R. Keeton \& J. O'Connell, Basic Protection for the Traffic Victim (1965): Kozyris, No-Fault Automobile Insurance and the Conflict of Laws-Cutting the Gordian Knot Home-Style, 1972 DUKE L.J. 331. 
the BarChris case. It is hardly conceivable that buyers could be protected against all losses for all time on condition of finding a flaw in the registration statement. It is conceivable, however, that buyers could be insured against a market loss of more than 50 percent within twelve months if a misrepresentation were discovered within that time. This result would have the merit of mitigating the most unexpected losses of many investors. The cost would be borne by the entire community of security buyers, augmented by the expenses of insurance underwriting and administration. The function of this type of insurance would be similar to that of Federal Deposit Insurance on bank accounts. To deter misrepresentation, we would rely on administrative remedies-for example, stop orders-and on criminal penalties.

If security buyers were like bank depositors-embracing the rank and file of humanity and relying on their securities as their principal shelter against a rainy day-such insurance could be recommended. If, however, security buyers are generally among the financially stronger individuals and institutions, with their own programs of diversification, they would probably be better off bearing their own risks. The latter hypothesis seems more likely to be true, and no-fault insurance for directors' errors appears to be a needless encumbrance on the money markets.

\section{Alternative Structures of Corporate Management}

More hopeful than restructuring liability damages and liability insurance are the possibilities of increasing the incentives for optimum performance by directors. With respect to other employees, everyone would agree that performance is more likely to be improved by rewards than the threat of fines, which are seldom used today except against fractious baseball players. Athletes, artists, musicians, scholars and politicians usually find their incentives in promotions and pay raises rather than in fear of punishment administered through civil liability. Similarly, there are many ways in which the good performances of directors can be rewarded, instead of, or in addition to, penalizing their errors.

This article is not the place to describe a whole new system of management, but it is a good place to indicate some of the ways in which incentives for director excellence could be enhanced. One must bear these possibilities in mind in order to place negligence liability in its proper perspective.

The first step in optimizing director behavior is to define direc- 
tors' tasks in ways which are attainable. Prevailing corporation statutes provide that directors shall "manage the business" of the corporation. However, management in any meaningful sense is impossible for outside directors, since they cannot familiarize themselves with corporate affairs sufficiently to be effective decision-makers. Their function, rather, is to decide whether the inside directors are doing a reasonably good job. ${ }^{71}$ For example, outside directors should not participate in management decisions, such as whether to buy Missouri Pacific bonds, ${ }^{72}$ or to move the manganese plant from Paterson to Colwyn. ${ }^{73}$ By not participating, they would avoid the risk of liability. For similar reasons, outside directors should not be liable for misstatements in registration statements; they should not even be permitted to sign them, in view of their inadequate basis for certifying the statements' accuracy. They should, however, retain liability for failing to remove incompetent directors, or failing to call for investigation of symptoms of malfunction.

The principal incentives for diligence of outside directors should be found in their relations to those whom they represent. The difficulty at present is that most outside directors represent the officers, who have chosen them through the proxy system. From these electors, they can seldom win plaudits for criticism, and never for suggesting a change of leadership. ${ }^{74}$ Therefore, if outside directors are to perform their function of providing independent judgment, they must be chosen by investors, not by officers, and must be regarded as investors' representatives. Despite all that has been said about "proxy control," many directors are chosen today by outsiders, such as investment bankers or other corporations holding substantial blocks of stock. Unfortunately, rules have grown up which inhibit these directors from regarding themselves as representatives. For example, a shareholder who is represented by an outside director becomes liable for short-term trades under section 16(b) of the Securities Exchange Act. ${ }^{75}$ This circumstance precludes active participation in control by

71. See Bunting, Conard, Deutsch, Farrell \& Hickman, The Corporate Machinery for Hearing and Heeding New Voices, 27 Bus. Law. 195, 214-16 (1971); Conard, Mace, Blough \& Gibson, Finctions of Directors Under the Existing System, 27 Bus. Law. 32 (Special Issue, Feb. 1972).

72. See Litwin v. Allen, 25 N.Y.S.2d 667 (Sup. Ct. 1940).

73. See Selheimer v. Manganese Corp. of America, 423 Pa. 563, 224 A.2d 634 (1966).

74. See Conard, Mace, Blough \& Gibson, supra note 71, at 35-36, 41-46.

75. Feder v. Martin Marietta Corp., 406 F.2d 260 (2d Cir. 1969), cert. denied, 396 U.S. 1036 (1970). 
the most powerful and best qualified stockholders-the institutional investors. There are also dangers of liability under "controlling persons" provisions of the securities acts. ${ }^{76}$ These provisions are major obstacles to effective control of large publicly-held corporations. They should be repealed or constricted if shareholder control of corporations is to be a reality.

These changes in the roles of outside directors would require a considerable change in statutory law. The clean-cut method would be to establish a supervisory council of outsiders, a system which has long existed in Germany and is gaining favor throughout the European communities. ${ }^{77} \mathrm{~A}$ more gradual approach in the same direction could be made by statutory recognition of an "auditing committee" in the board, with decreased responsibility for active management and increased powers of control..$^{78}$

With respect to "inside directors," who are the executive officers, incentives for optimum performance could be provided by subjecting them to the effective control of a supervisory council or auditing committee. This approach would require removing the proxy power from the executives and placing it in the hands of the outsiders. The supervisory council or auditing committee would then be in a position to reward the executives for excellence by retaining them in office (the principal incentive of public officials), by promoting them (the usual incentive of non-executive employees), or by the bonuses and stock options which are traditional incentives for executives. These rewards would, however, be determined by an evaluation of performance, rather than by swings in the economic cycle which are often unrelated to excellence.

If observers of the corporate scene became convinced that executives are subject to effective and independent supervision, they might willingly accept a diminution or even an abandonment of the clumsy threat of liability for damages. It is largely the lack of faith in other

76. Section 15 of the Securities Act of 1933,15 U.S.C. $\$ 770$ (1970), in conjunction with section 5, prohibits a controlling person from selling securities without a prospectus except within narrow limits set by rule. Section 20(a) of the Securities Exchange Act of 1934, 15 U.S.C. $\$ 78 t$ (1970), imposes a prima facie liability on controlling persons for securities violations by persons controlled.

77. German Stock Corporation Act, Laws of Sept. 6, 1965, [1965] BGBI 1089, 1185. See also French Law on Commercial Companies, Law of July 24, 1966, [1966] J.O. 6402. See generally Vagts, The European System, 27 Bus. Law. 165 (Special Issue, Feb. 1972); Vagts, Reforming the "Modern" Corporation: Perspectives from the German, 80 HARV. L. REv. 23 (1966).

78. Cary \& Harris, supra note 4, at 72-73, citing ONTARIo Bus. CORP. ACT $\$ 182$ (1970). 
controls over directors which inspires critics to complain so bitterly of the indemnification and insurance devices which presently emasculate the liability threat. ${ }^{79}$

\section{CONCLUSION}

The simple principle of directors' liability for negligence-designed to punish directors and compensate injured investors-presently functions with pathetic inefficiency and sometimes not at all. Substantial sums of money are invested in making the principle work, but it is like a propellor so fouled with seaweed that it no longer moves the ship, regardless of the power input. The fouling is primarily caused by indemnification and insurance, which are supplied at the expense of the same people, or some of the same people, who are supposed to be benefited. Since aggregate net benefits are slight in relation to costs, investors as a whole are more harmed than helped.

The problem cannot be solved simply by taking away indemnification and insurance; such a development would result not in getting better directors, but in getting worse ones-those who are indifferent to potentially bankrupting liabilities. If liability is to work efficiently, a scaling down of the limits of liability must be initiated simultaneously with elimination of indemnification and insurance. The measure of damages should be related to directors' compensation, rather than to corporations' or investors' losses.

But liability is a blunt instrument at best. A more positive way of stimulating directors' excellence is to provide them with a highly qualified, completely independent supervisory board or auditing committee. To be independent, such a board or committee would have to be chosen by investors, without the interposition of officers, as proxy-holders or otherwise. Active investor participation might be stimulated by liberating the big shareholders, including institutional investors, from liabilities which would now threaten them if they exercised active control over the corporations in which they have placed their funds.

79. See Bishop, supra note 3. 
